Article

\title{
Affects of Mechanical Milling and Metal Oxide Additives on Sorption Kinetics of 1:1 $\mathrm{LiNH}_{2} / \mathrm{MgH}_{2}$ Mixture
}

\section{Donald L. Anton *, Christine J. Price and Joshua Gray}

Savannah River National Laboratory/Aiken, SC 29803, USA; E-Mails: christine.erdy@srs.gov (C.J.P.); joshua.gray@srnl.doe.gov (J.G.)

* Author to whom correspondence should be addressed; E-Mail: donald.anton@srnl.doe.gov;

Tel.: +1-803-507-8551; Fax: +1-803-652-8137.

Received: 18 March 2011; in revised form: 5 May 2011 / Accepted: 6 May 2011 /

Published: 20 May 2011

\begin{abstract}
The destabilized complex hydride system composed of $\mathrm{LiNH}_{2}: \mathrm{MgH}_{2}$ (1:1 molar ratio) is one of the leading candidates of hydrogen storage with a reversible hydrogen storage capacity of $8.1 \mathrm{wt} \%$. A low sorption enthalpy of $\sim 32 \mathrm{~kJ} / \mathrm{mole} \mathrm{H}_{2}$ was first predicted by Alapati et al. utilizing first principle density function theory (DFT) calculations and has been subsequently confirmed empirically by Lu et al. through differential thermal analysis (DTA). This enthalpy suggests that favorable sorption kinetics should be obtainable at temperatures in the range of $160{ }^{\circ} \mathrm{C}$ to $200{ }^{\circ} \mathrm{C}$. Preliminary experiments reported in the literature indicate that sorption kinetics are substantially lower than expected in this temperature range despite favorable thermodynamics. Systematic isothermal and isobaric sorption experiments were performed using a Sievert's apparatus to form a baseline data set by which to compare kinetic results over the pressure and temperature range anticipated for use of this material as a hydrogen storage media. Various material preparation methods and compositional modifications were performed in attempts to increase the kinetics while lowering the sorption temperatures. This paper outlines the results of these systematic tests and describes a number of beneficial additions which influence kinetics as well as $\mathrm{NH}_{3}$ formation.
\end{abstract}

Keywords: hydrogen storage; lithium amide; magnesium hydride; isothermal kinetics; oxide 


\section{Introduction}

Development of high-performance on-board hydrogen storage systems are recognized as critical to implementation of hydrogen fuel cells as clean, efficient automotive power plants [1]. Among the various condensed phase storage system types - adsorbent materials, chemical hydrides and metal hydrides - the use of complex metal hydrides are being studied due to their combined favorable gravimetric and volumetric storage capacities [2], on-board reversibility, and indefinite ambient temperature storage duration.

In 2002, Chen et al. identified a hydrogen storage system based on the rehydrogenation of lithium nitride $\left(\mathrm{Li}_{3} \mathrm{~N}\right)$ in the following reactions [3]:

$$
\mathrm{Li}_{3} \mathrm{~N}+2 \mathrm{H}_{2} \Leftrightarrow \mathrm{Li}_{2} \mathrm{NH}+\mathrm{LiH}+\mathrm{H}_{2} \Leftrightarrow \mathrm{LiNH}_{2}+2 \mathrm{LiH}
$$

Even though both steps are reversible and contain an overall hydrogen capacity of $11.5 \mathrm{wt} \%$, a dehydriding enthalpy of $\sim 66 \mathrm{~kJ} / \mathrm{mol} \mathrm{H}_{2}$ [4] allows only the rightmost reaction to release hydrogen gas under practical conditions [1,5]. This is due to strong polar covalent bonds between hydrogen and nitrogen in $\mathrm{NH}^{2-}$ and to the strong ionic bonds that hold the $\mathrm{H}^{-}$in the case of $\mathrm{LiH}$ [6].

With the substitution of $\mathrm{LiH}$ with $\mathrm{MgH}_{2}$ and the subsequent destabilizing of the hydrogen bonds, the $\mathrm{Li}-\mathrm{Mg}-\mathrm{N}$ system has became one of the most promising systems with its relatively high hydrogen content and favorable thermodynamics [7,8]. Through the research of Luo [5,7,9] and Xiong [10], a 2:1 molar mixture of $\mathrm{LiNH}_{2}$ and $\mathrm{MgH}_{2}$, or the equivalent $\mathrm{Mg}\left(\mathrm{NH}_{2}\right)_{2}$ and $2 \mathrm{LiH}$ mixture due to the metathesis reaction between the two metal hydride - amide pairs which occurs at $220{ }^{\circ} \mathrm{C}$ under 100 bar of $\mathrm{H}_{2}$ pressure [5,11], has been shown to have a theoretical hydrogen capacity of $5.5 \mathrm{wt} \% \mathrm{H}_{2}$. Both $\mathrm{X}$-ray diffraction and IR spectroscopy [12] have shown that the overall reversible reaction can be written as:

$$
2 \mathrm{Li}_{2} \mathrm{NH}+\mathrm{MgH}_{2} \rightarrow \mathrm{Li}_{2} \mathrm{Mg}(\mathrm{NH})_{2}+2 \mathrm{H}_{2} \Leftrightarrow \mathrm{Mg}\left(\mathrm{NH}_{2}\right)_{2}+2 \mathrm{LiH}
$$

After 9 cycles, the $2: 1$ system has been shown to have a capacity of $4.59 \mathrm{wt} \% \mathrm{H}_{2}$ [7]. Through the use of deuterium absorption and in-situ neutron diffraction, the absorption reaction pathway was investigated by Weidner et al. [13] who observed that the immediate absorption reaction can be stated as:

$$
2 \mathrm{Li}_{2} \mathrm{Mg}(\mathrm{ND})_{2}+4 \mathrm{D}_{2} \rightarrow \mathrm{LiD}+\mathrm{LiND}_{2}+\mathrm{Li}_{2} \mathrm{Mg}(\mathrm{ND})_{3} \rightarrow 4 \mathrm{LiD}+2 \mathrm{Mg}\left(\mathrm{ND}_{2}\right)_{2}
$$

In a separate neutron diffraction study, Dolci et al. observed the formation of $\mathrm{LiNH}_{2}$ and $\mathrm{Li}_{2} \mathrm{Mg}_{2}(\mathrm{NH})_{3}$ with an increase in the amount of $\mathrm{LiH}$ for desorbed material, $\mathrm{Li}_{2} \mathrm{Mg}(\mathrm{NH})_{2}$, at $200{ }^{\circ} \mathrm{C}$ and equilibrium pressures below 40 bar [14]. $\mathrm{Mg}\left(\mathrm{NH}_{2}\right)_{2}$ formation was not observed until the pressure was raised about 40 bar at $200{ }^{\circ} \mathrm{C}$ [14]. Araújo et al. predicted an enthalpy of $46.1 \mathrm{~kJ} / \mathrm{mol} \mathrm{H}_{2}$ for the reversible reaction [6], which is slightly higher than the experimental values of $39 \mathrm{~kJ} / \mathrm{mol} \mathrm{H}_{2}$ measured by Luo [7] and the $41.6 \mathrm{~kJ} / \mathrm{mol} \mathrm{H}_{2}$ measured by Yang et al. [15].

In order to understand if the reaction was ammonia-mediated or a coordinated two-molecule or mutlimolecular reaction mechanism, Chen et al. performed both isothermal and non-isothermal kinetic measurements on the reaction between $\mathrm{Mg}\left(\mathrm{NH}_{2}\right)_{2}$ and $\mathrm{LiH}$ [16]. It was concluded that in the early stages of the reaction, the kinetic barrier may result from the interface reaction between the amide and 
hydride; however, as the reaction progressed, the resistance of mass transport through the product layer increased and becomes the rate-determining step [16].

Different molar ratios of $\mathrm{Mg}\left(\mathrm{NH}_{2}\right)_{2}$ and $\mathrm{LiH}$ have also been explored for promising hydrogen storage systems. Leng et al. investigated the hydrogen desorption reaction between 8:3 $\mathrm{LiH}: \mathrm{Mg}\left(\mathrm{NH}_{2}\right)_{2}$ mixture [8]. From TGA analysis, the first desorption of the milled 8:3 mixture resulted in hydrogen desorption starting at $140{ }^{\circ} \mathrm{C}$ at a heating rate of $5{ }^{\circ} \mathrm{C} / \mathrm{min}$ with minimal ammonia release and $6.9 \mathrm{wt} \%$ hydrogen released by $400{ }^{\circ} \mathrm{C}$. After heating the mixture to $400{ }^{\circ} \mathrm{C}$, XRD revealed that the desorption reaction proceeds via:

$$
3 \mathrm{Mg}\left(\mathrm{NH}_{2}\right)_{2}+8 \mathrm{LiH} \rightarrow \mathrm{Mg}_{3} \mathrm{~N}_{2}+4 \mathrm{Li}_{2} \mathrm{NH}+8 \mathrm{H}_{2}
$$

An XRD analysis has confirmed that the above reaction is reversible at $200{ }^{\circ} \mathrm{C}$ under $3 \mathrm{MPa}$ of hydrogen [8,17]. However, during dehydrogenation at $250{ }^{\circ} \mathrm{C}$, Aoki et al. observed that 5.1 mass \% hydrogen had been desorbed [18]. The XRD spectra taken after dehydrogenation showed:

$$
3 \mathrm{Mg}\left(\mathrm{NH}_{2}\right)_{2}+8 \mathrm{LiH} \rightarrow 3 \mathrm{Li}_{2} \mathrm{Mg}(\mathrm{NH})_{2}+2 \mathrm{LiH}+6 \mathrm{H}_{2}
$$

and that subsequent dehydrogenation of $3 \mathrm{Li}_{2} \mathrm{Mg}(\mathrm{NH})_{2}$ was not observed at $250{ }^{\circ} \mathrm{C}$, indicating that complete dehydrogenation to $\mathrm{Mg}_{3} \mathrm{~N}_{2}$ and $\mathrm{Li}_{2} \mathrm{NH}$ does not occur till higher temperature [18].

A two step dehydrogenation reaction was predicted for the 8:3 ratio: the first step being the conversion from $3 \mathrm{Mg}\left(\mathrm{NH}_{2}\right)_{2}+8 \mathrm{LiH}$ to $3 \mathrm{Li}_{2} \mathrm{Mg}(\mathrm{NH})_{2}+2 \mathrm{LiH}+6 \mathrm{H}_{2}$ with an enthalpy of $46.1 \mathrm{~kJ} / \mathrm{mol} \mathrm{H}$ and the second step being the final conversion to $4 \mathrm{Li}_{2} \mathrm{NH}+\mathrm{Mg}_{3} \mathrm{~N}_{2}+8 \mathrm{H}_{2}$ with an enthalpy of $84.1 \mathrm{~kJ} / \mathrm{mol} \mathrm{H}_{2}$ [6]. Araújo et al. stated that if $\mathrm{Li}_{2} \mathrm{Mg}(\mathrm{NH})_{2}$ did not stabilize, the reaction enthalpy would be $55.6 \mathrm{~kJ} / \mathrm{mol} \mathrm{H}_{2}$ [6].

When the ratio between $\mathrm{Mg}\left(\mathrm{NH}_{2}\right)_{2}: \mathrm{LiH}$ was increased to $1: 4$, the hydrogen capacity of the $\mathrm{Li}-\mathrm{Mg}-\mathrm{N}-\mathrm{H}$ system increased to $9.1 \mathrm{wt} \%$ [19-21]. Reversible sorption is proposed to occur via the following reaction:

$$
3 \mathrm{Mg}\left(\mathrm{NH}_{2}\right)_{2}+12 \mathrm{LiH} \rightarrow \mathrm{Mg}_{3} \mathrm{~N}_{2}+4 \mathrm{Li}_{3} \mathrm{~N}+12 \mathrm{H}_{2}
$$

The dehydrogenation reaction has been observed to begin at approximately $227^{\circ} \mathrm{C}$ at a heating rate of $10 \mathrm{~K} / \mathrm{min}$ under $0.1 \mathrm{MPa}$ of argon; however, only $8 \mathrm{mass} \%$ had been desorbed by $427^{\circ} \mathrm{C}[21]$.

Aoki et al. investigated the dehydriding and structural properties of the $1: 4 \mathrm{LiH}: \mathrm{Mg}\left(\mathrm{NH}_{2}\right)_{2}$ system under hydrogen pressure using the p-c isotherm measurement and XRD [18,19]. The total amount of desorbed hydrogen at 200,225 , and $250{ }^{\circ} \mathrm{C}$ were $4.5,4.7$, and 4.9 mass $\%$, respectively with a calculated enthalpy of hydrogenation of $-46 \mathrm{~kJ} / \mathrm{mol} \mathrm{H}_{2}$ [19]. Based upon the XRD spectra after dehydrogenation at $250{ }^{\circ} \mathrm{C}$ under hydrogen pressure, the dehydrogenation process is proposed as:

$$
3 \mathrm{Mg}\left(\mathrm{NH}_{2}\right)_{2}+12 \mathrm{LiH} \rightarrow 3 \mathrm{Li}_{2} \mathrm{Mg}(\mathrm{NH})_{2}+6 \mathrm{LiN}+6 \mathrm{H}_{2}
$$

and there was no indication of further dehydrogenation of $3 \mathrm{Li}_{2} \mathrm{Mg}(\mathrm{NH})_{2}$ [18].

In 2002, Alapati et al. predicted that the reaction between 1:1 $\mathrm{MgH}_{2}$ and $\mathrm{LiNH}_{2}$ was energetically favorable with an enthalpy of $31.9 \mathrm{~kJ} / \mathrm{mol} \mathrm{H}_{2}$ through the use of first principle density function theory (DFT) [22]. The dehydrogenation reaction pathway is as follows:

$$
\mathrm{LiNH}_{2}+\mathrm{MgH}_{2} \rightarrow \mathrm{LiMgN}+2 \mathrm{H}_{2}
$$

This mixture has a theoretical hydrogen weight capacity of $8.2 \mathrm{wt} \%$. 
Through a separate first-principle calculations of total energies and vibrations free energies, Akbarzadeh et al. suggested that the initial decomposition of 1:1 $\mathrm{LiNH}_{2}: \mathrm{MgH}_{2}$ will proceed as in a series of reaction steps [4]:

$$
\begin{aligned}
\mathrm{LiNH}_{2}+\mathrm{MgH}_{2} & \rightarrow \mathrm{LiH}+\frac{1}{2} \mathrm{Mg}\left(\mathrm{NH}_{2}\right)_{2}+\frac{1}{2} \mathrm{MgH}_{2} \\
& \rightarrow \mathrm{LiH}+\frac{1}{4} \mathrm{Mg}\left(\mathrm{NH}_{2}\right)_{2}+\frac{1}{4} \mathrm{Mg}_{3} \mathrm{~N}_{2}+\mathrm{H}_{2} \\
& \rightarrow \frac{1}{2} \mathrm{LiH}+\frac{1}{4} \mathrm{Mg}_{3} \mathrm{~N}_{2}+\frac{1}{4} \mathrm{Li}_{2} \mathrm{Mg}\left(\mathrm{NH}_{2}\right)_{2}+\frac{3}{2} \mathrm{H}_{2} \\
& \rightarrow \mathrm{LiMgN}+2 \mathrm{H}_{2}
\end{aligned}
$$

The formation of magnesium amide, which is the first step in the decomposition pathway, was predicted to be exothermic. In the next step $\mathrm{Mg}_{3} \mathrm{~N}_{2}$ and $\mathrm{H}_{2}$ would be formed from the $\mathrm{MgH}_{2}$ and half of the $\mathrm{Mg}\left(\mathrm{NH}_{2}\right)_{2}$ in an endothermic reaction with an enthalpy of $15 \mathrm{~kJ} / \mathrm{mol} \mathrm{H}_{2}$ [4]. A mixed $\mathrm{Li}-\mathrm{Mg}$ imide would be produced in the next step with an enthalpy of $47 \mathrm{~kJ} / \mathrm{mol} \mathrm{H}_{2}$ [4]. Finally, $\mathrm{LiMgN}$ is formed with an enthalpy of $80 \mathrm{~kJ} / \mathrm{mol} \mathrm{H}_{2}$ at $227^{\circ} \mathrm{C}$ [4].

Experimental, $\mathrm{Lu}$ et al. found that after jar rolling for 12 to $24 \mathrm{~h}$, the $1: 1 \mathrm{LiNH}_{2}: \mathrm{MgH}_{2}$ mixture started to release hydrogen around $120{ }^{\circ} \mathrm{C}$ and released $8.1 \mathrm{wt} \%$ after being held at $220{ }^{\circ} \mathrm{C}$ for $20 \mathrm{~min}$ [23]. The material was able to successfully uptake $5 \mathrm{wt} \%$ when heated to $240{ }^{\circ} \mathrm{C}$ under 2000 psi [23]. With the addition of $\mathrm{TiCl}_{3}$ as a modifier, the system was able to uptake $8 / 0 \mathrm{wt} \%$ from the rehydrogenation process at $2000 \mathrm{psi}, 160{ }^{\circ} \mathrm{C}$ for $6 \mathrm{~h}[23,24]$. The proposed rehydrogenation and subsequent dehydrogenation process of $\mathrm{LiMgN}$ produces $\mathrm{LiH}, \mathrm{Mg}\left(\mathrm{NH}_{2}\right)_{2}$ and $\mathrm{MgH}_{2}$, as [23]:

$$
\mathrm{LiMgN}+2 \mathrm{H}_{2} \leftrightarrow \frac{1}{2} \mathrm{Mg}\left(\mathrm{NH}_{2}\right)_{2}+\frac{1}{2} \mathrm{MgH}_{2}+\mathrm{LiH}
$$

It has been further suggested by Luo et al. [21] that the rehydrogenation pathway is not directly back to the hydrogenated state, but via an intermediate hydride as given by:

$$
\mathrm{LiMgN}+\mathrm{H}_{2} \rightarrow \mathrm{Li}_{2 x} \mathrm{Mg}_{1-x}(\mathrm{NH})_{2}+\mathrm{MgH}_{2}+\mathrm{H}_{2} \rightarrow \frac{1}{2} \mathrm{Mg}\left(\mathrm{NH}_{2}\right)_{2}+\frac{1}{2} \mathrm{MgH}_{2}+\mathrm{LiH}
$$

The mixture does not rehydrogenate back to $\mathrm{LiNH}_{2}$ and $\mathrm{MgH}_{2}$ but rather to $\mathrm{LiH}, \mathrm{MgH}_{2}$ and $\mathrm{Mg}\left(\mathrm{NH}_{2}\right)_{2}$ as shown in equation (4) [5].

Further investigations into the 1:1 system show that the kinetics and capacity are highly dependent on processing techniques and experimental conditions. In a study involving Fritsch milling, Liu et al. found that milling for $12 \mathrm{~h}$ resulted in $\mathrm{LiH}$ and $\mathrm{Mg}\left(\mathrm{NH}_{2}\right)_{2}$ formation with unreacted $\mathrm{MgH}_{2}$ while milling for $36 \mathrm{~h}$ also formed $\mathrm{MgNH}[25,26]$. This resulted in a reduction of the weight capacity to $6.1 \mathrm{wt} \%$, a higher experimental enthalpy value of $45.9 \mathrm{~kJ} / \mathrm{mol} \mathrm{H}_{2}$ and the formation of $\mathrm{Li}_{2} \mathrm{Mg}(\mathrm{NH})_{2}$, $\mathrm{Mg}_{3} \mathrm{~N}_{2}$ and $\mathrm{LiH}$ after heating to $390{ }^{\circ} \mathrm{C}$ [25]. In another investigation into the 1:1 molar mixture, Osborn et al. milled the sample for $3 \mathrm{~h}$ under argon with a Szegvari attritor, which upon heating to $550{ }^{\circ} \mathrm{C}$ at $5{ }^{\circ} \mathrm{C} / \mathrm{min}$ released $8.73 \mathrm{wt} \%$ [27]. Ammonia emission was found to begin around $260{ }^{\circ} \mathrm{C}$ with a concentration of $16.4 \mathrm{ppm} \mathrm{mg}^{-1}$, which was attributed to the slow kinetics of converting $\mathrm{NH}_{3}$ to 
$\mathrm{H}_{2}$ using $\mathrm{MgH}_{2}$ [27]. Upon PCI measurements at $210^{\circ} \mathrm{C}$, only $3.4 \mathrm{wt} \%$ was released forming $\mathrm{Li}_{2} \mathrm{Mg}_{2}(\mathrm{NH})_{3}$ and $\mathrm{LiH}[27]$.

The observations cited above can be readily summarized by studying the quaternary phase diagram of the $\mathrm{Li}, \mathrm{Mg}, \mathrm{N}, \mathrm{H}$ system given in Figure 1.

Figure 1. Pseudo quaternary phase diagram of the $\mathrm{Li}-\mathrm{Mg}-\mathrm{N}-\mathrm{H}$ system showing relative phase compositions of known phases relevant to hydrogen sorption.

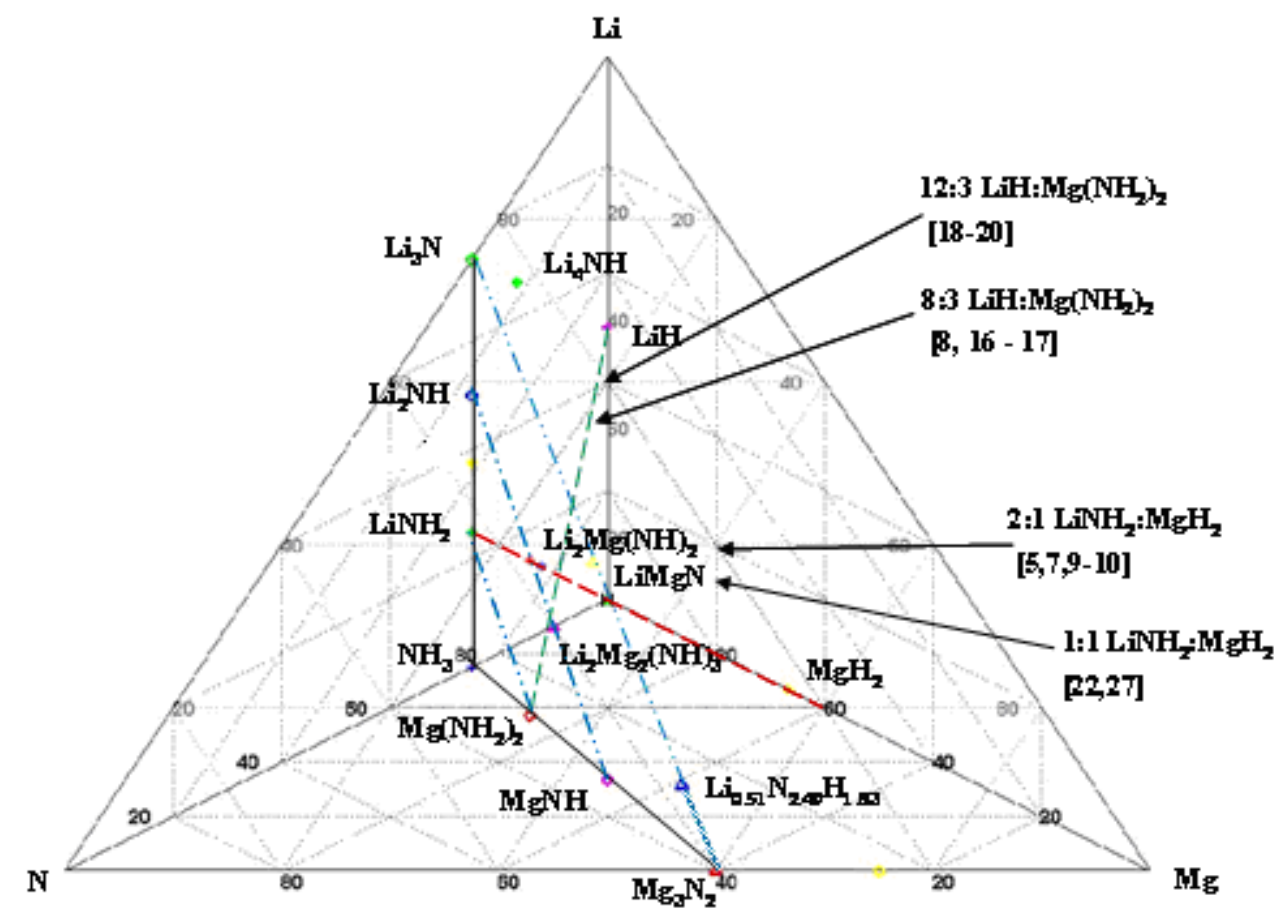

Here the ternary $\mathrm{Li}, \mathrm{N}, \mathrm{Mg}$ phase diagram is given in the plane of the page with hydrogen coming directly out of the page plane and lying directly above the ternary LiMgN phase. This ternary diagram is constructed by inserting all of the known phases by atom fraction for this system without regard to temperature or pressure, thus it is not an equilibrium phase diagram. The tie lines connecting $\mathrm{Li}_{3} \mathrm{~N}$ with $\mathrm{NH}_{3}$ and $\mathrm{Mg}_{3} \mathrm{~N}_{2}$ with $\mathrm{NH}_{3}$ show the outer extreme of these ternary concentrations. Between these two tie lines one sees a plane of descending hydrogen concentration with its apex at $\mathrm{NH}_{3}$ and descending through the amides $\mathrm{LiNH}_{2}-\mathrm{Mg}\left(\mathrm{NH}_{2}\right)_{2}$, imides $\mathrm{Li}_{2} \mathrm{NH}-\mathrm{MgNH}$ and finally to the nitrides $\mathrm{Li}_{3} \mathrm{~N}-\mathrm{Mg}_{3} \mathrm{~N}_{2}$.

Many of the recent publications on materials in this phase space have centered either on the $\mathrm{LiNH}_{2}: \mathrm{MgH}_{2}$ tie line at the $2: 1 \mathrm{Li}: \mathrm{Mg}$ concentrations or along the $\mathrm{LiH}-\mathrm{Mg}\left(\mathrm{NH}_{2}\right)_{2}$ tie line along the higher LiH concentrations. It is clearly shown that all compositions along this tie line will miss the LiMgN decomposition and likely result in one of the imides: $\mathrm{Li}_{2} \mathrm{NH}, \mathrm{Li}_{2} \mathrm{Mg}(\mathrm{NH})_{2}$ or $\mathrm{Li}_{2} \mathrm{Mg}_{2}(\mathrm{NH})_{3}$. At high $\mathrm{LiNH}_{2}$ concentrations, dehydrogenation will result in composition to either $\operatorname{Li}_{2} \mathrm{Mg}_{2}(\mathrm{NH})_{3}$ or $\mathrm{Li}_{2} \mathrm{Mg}(\mathrm{NH})_{2}$. Through theoretically computed structural energetics, these compositions have been shown to be stable, $\Delta H_{T=500 \mathrm{~K}}^{\text {vib }}=128.5$ and $200.7 \mathrm{~kJ} / \mathrm{mol} \mathrm{H}_{2}$ [28], and not to give up further hydrogen at temperatures of potential utilization below $200{ }^{\circ} \mathrm{C}[5,7,9]$. These structures have yet to be indentified experimentally. Similarly, with no $\mathrm{Mg}$ present, the terminal phase is the $\mathrm{Li}_{2} \mathrm{NH}$. However, with the additional of $\mathrm{MgH}_{2}$, at the $\mathrm{Li}: \mathrm{Mg}$ ratio of $1: 1$, these amine phases can be avoided resulting in the 
terminal $\mathrm{LiMgN}$ and complete hydrogen release [23]. This decomposition has been shown to occur at temperatures as low at $120{ }^{\circ} \mathrm{C}$ and can be rehydrogenated under 138 bar [23]

In this paper, we investigate the base line isothermal and isobaric sorption kinetics of the 1:1 $\mathrm{LiNH}_{2}: \mathrm{MgH}_{2}$.composition. Qualitative gas stream chemistries were monitored to differentiate between hydrogen and ammonia discharge. The effects of various dopants on sorption rates, the temperature of initial hydrogen release and the amount of ammonia released were subsequently investigated. Implications for use of this material for hydrogen storage applications are summarized.

\section{Results and Discussion}

\subsection{Unmodified System}

\subsubsection{Characterization of Unmodified As-Milled Material}

The XRD pattern of the milled 1:1 molar mixture of $\mathrm{LiNH}_{2}$ and $\mathrm{MgH}_{2}$ revealed only the starting materials with no phase changes or reactions occurring during the milling process.

Figure 2. XRD pattern for the Fritsch milled (top) and Spex milled (bottom) samples.

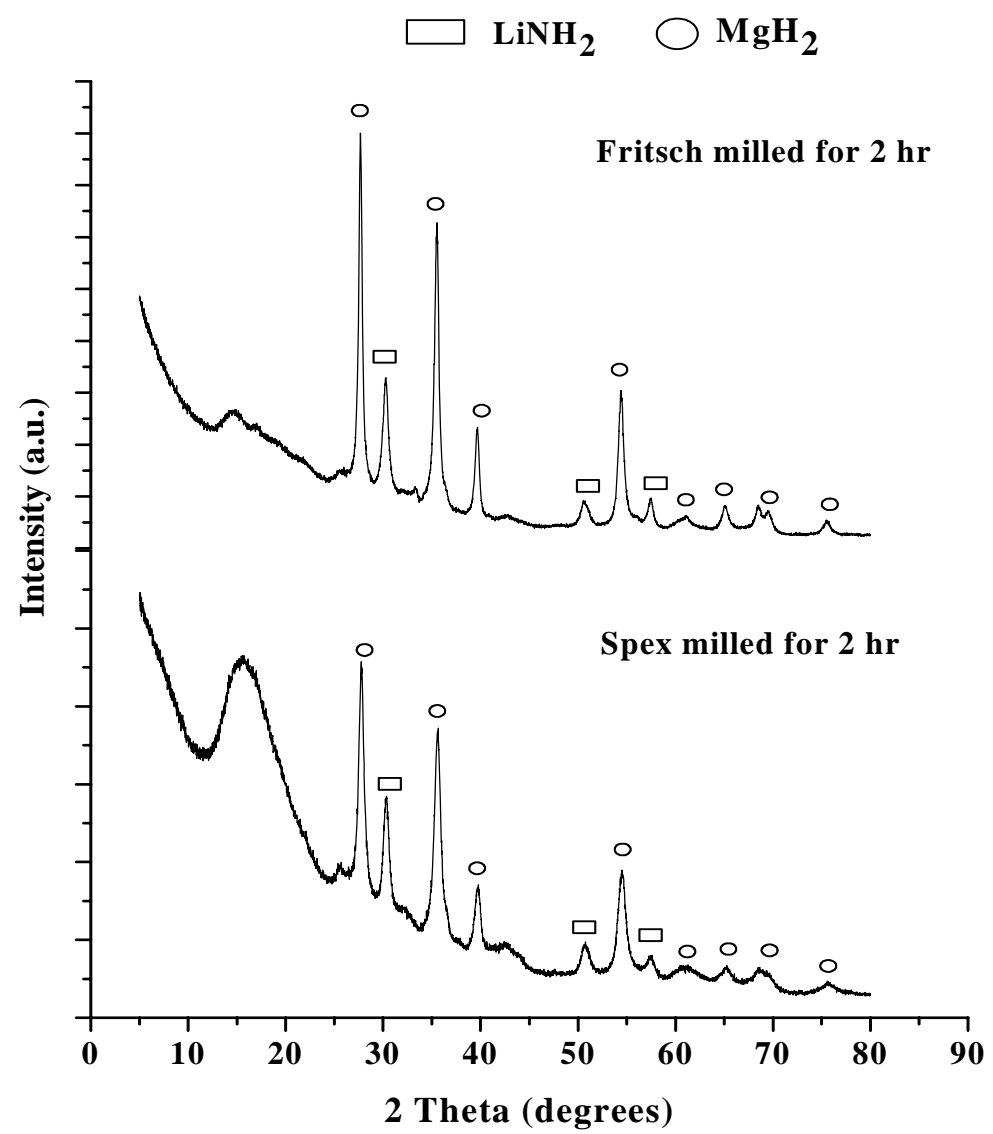

This is evident by the $\mathrm{MgH}_{2}$ peaks, denoted by circles in Figure 2, and $\mathrm{LiNH}_{2}$, denoted by rectangles. These results are similar to those observed by Liu et al. after milling for $2 \mathrm{~h}$ at $500 \mathrm{rpm}$ on the Fritsch mill [25] and Lu et al. after milling for 30 min on the Spex mill [24]. The broad peak seen in the lower angle region is attributed to the kapton film used to prevent oxidation of the samples 
during measurement. The pattern of the Spex milled sample did reveal peak broadening and lower intensity indicating a decrease in particle size and an increase in defects [29]. Using the Scherrer equation to determine particle size from XRD patterns, the average $\mathrm{MgH}_{2}$ particle was reduced from $35.3 \mathrm{~nm}$ to $23.6 \mathrm{~nm}$.

\subsubsection{Decomposition Behavior of Unmodified As-Milled Material}

As discussed in our previous publication [30] the unmodified Fritsch milled sample started to desorb hydrogen at approximately $135{ }^{\circ} \mathrm{C}$ during ramping from $\mathrm{RT}$ to $400{ }^{\circ} \mathrm{C}$ at with heating at a rate of $5^{\circ} \mathrm{C} / \mathrm{min}[30]$.

Figure 3. TGA curves for Fritsch (red) and Spex (blue) milled unmodified 1:1 $\mathrm{LiNH}_{2}: \mathrm{MgH}_{2}$ mixture. The apparent slight increase in mass observed at the start of heating is attributed to the expansion of the argon carrier gas.

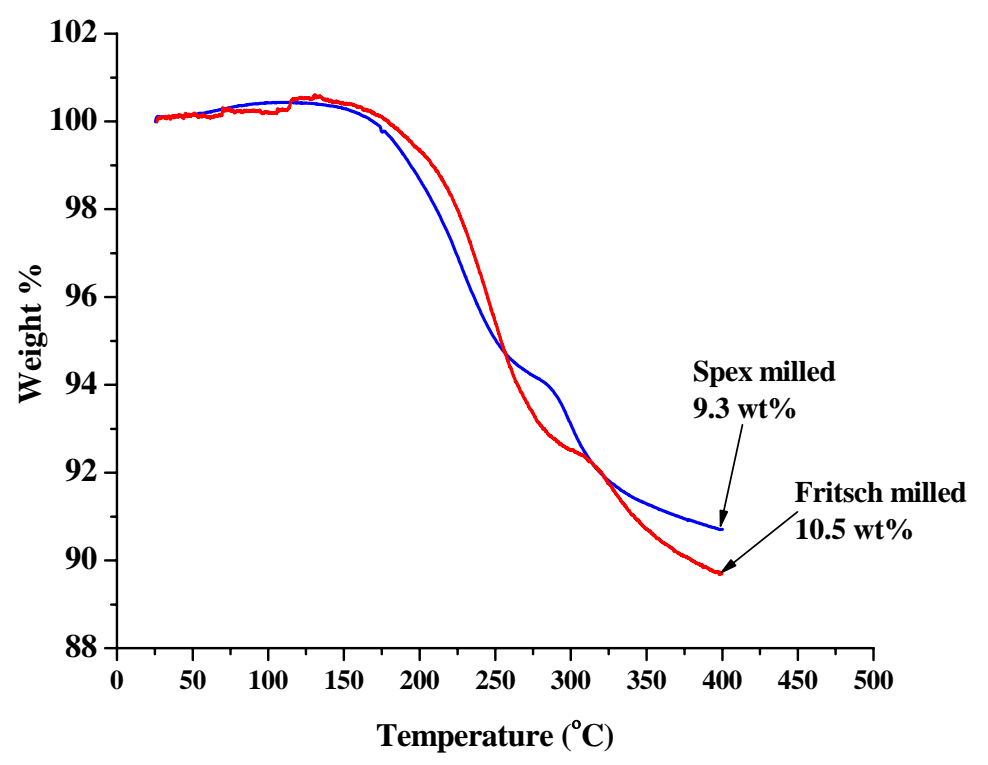

From the TGA results in Figure 3 and RGA data given in Figure 4A,B, hydrogen desorption for the Fritsch-milled unmodified material starts at approximately $135^{\circ} \mathrm{C}$ with three hydrogen peaks at $205^{\circ} \mathrm{C}, 260^{\circ} \mathrm{C}$, and $340^{\circ} \mathrm{C}$, indicating that the sample decomposed in three steps. It is possible to attribute these hydrogen releases to the decomposition reactions listed by Akbarzadeh et al. [4] as reviewed previously. An in-depth investigation of the dehydrogenation pathway is needed to confirm the proposed decomposition reactions. On the other hand, the Spex-milled material started to desorb hydrogen at approximately $120^{\circ} \mathrm{C}$ resulting in two defined hydrogen peaks at $230{ }^{\circ} \mathrm{C}$ and $330{ }^{\circ} \mathrm{C}$ with a shoulder at $218^{\circ} \mathrm{C}$. This reduction in initial dehydrogenation temperature can be attributed to the smaller particle size resulting from Spex-milled samples which resulted in increased surface area and lower surface activation energy [29,31,32]. 
Figure 4. RGA results for (A) hydrogen and (B) ammonia for Fritsch (red) and Spex (blue) milled material.
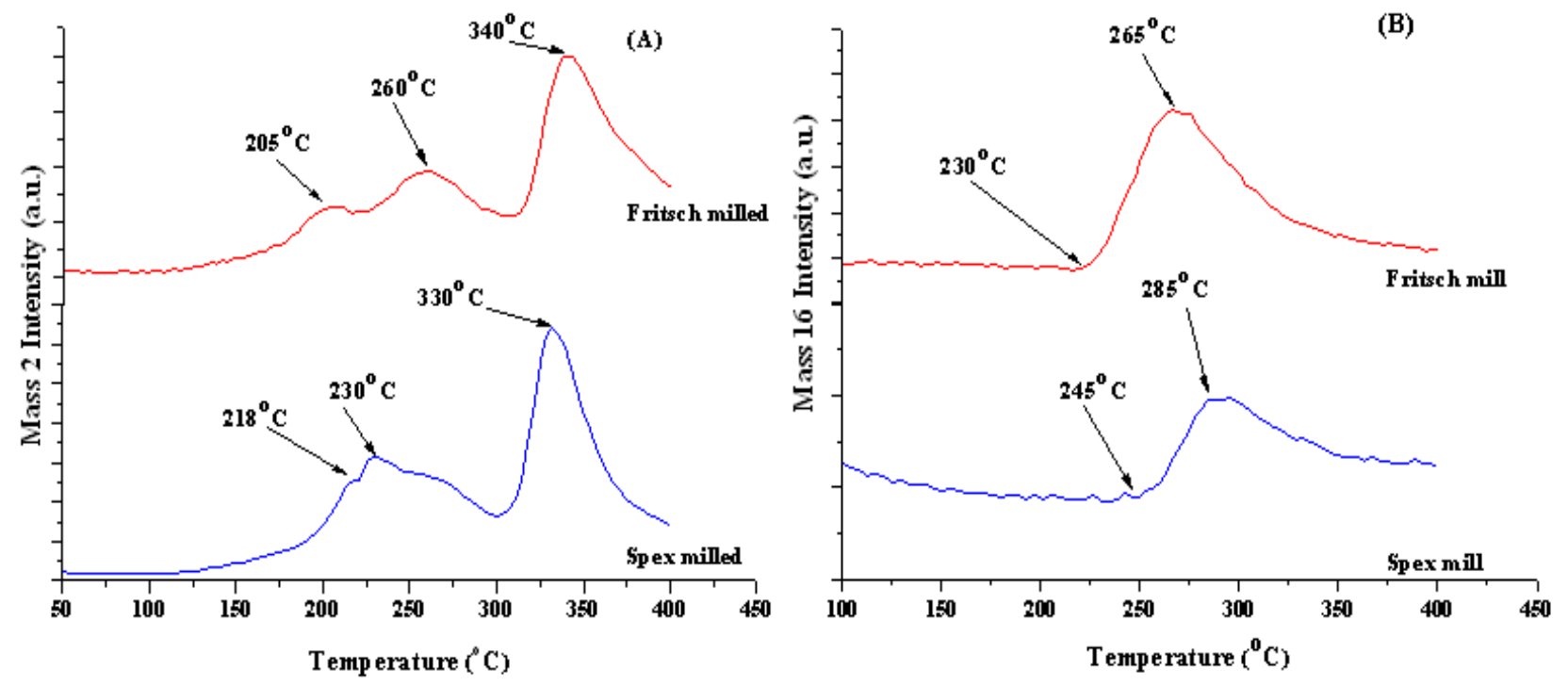

Ammonia release peaked at $265^{\circ} \mathrm{C}$ for the Fritsch milled sample, as shown in Figure 4B. Similarly, the ammonia release from the Spex milled sample peaked at $285^{\circ} \mathrm{C}$. The source of ammonia can be attributed to the decomposition of unreacted $\mathrm{LiNH}_{2}$, the slow reaction kinetics between $\mathrm{MgH}_{2}$ and $\mathrm{NH}_{3}$ from decomposing $\mathrm{LiNH}_{2}$ [12,33,34] and/or the decomposition of $\mathrm{Mg}\left(\mathrm{NH}_{2}\right)_{2}$, which runs parallel to the $\mathrm{H}_{2}$ desorption of the hydride-amide system [35]. Janot et al. showed that a mixture of 2:1 $\mathrm{LiNH}_{2}: \mathrm{MgH}_{2}$ lost significantly more weight than a 2:1 $\mathrm{LiH}: \mathrm{Mg}\left(\mathrm{NH}_{2}\right)_{2}$ at $200{ }^{\circ} \mathrm{C}$ into primary vacuum due to ammonia release [12].

At the end of the decomposition, the total weight lost for the Fritsch milled sample was $10.5 \mathrm{wt} \%$, and $9.3 \mathrm{wt} \%$ for the Spex milled sample. When comparing the predicted weight loss for each decomposition step to the observed weight loss, ammonia accounted for the additional 1.1 to $2.3 \mathrm{wt} \%$ above the theoretical hydrogen capacity of $8.2 \mathrm{wt} \%$. Not only did Spex milling increase the ammonia release temperature but it also reduced the amount of ammonia released, further indicating the importance of particle size on desorption kinetics.

\subsubsection{Isothermal Dehydrogenation/Hydrogenation Cycling of Unmodified System}

The effect of synthesis methods on the rates of isothermal dehydrogenation and rehydrogenation of unmodified 1:1 $\mathrm{LiNH}_{2}: \mathrm{MgH}_{2}$ were investigated. The following cycling processes were used: dehydrogenation at $200^{\circ} \mathrm{C}$ for $6 \mathrm{~h}$ into 1 bar of $\mathrm{H}_{2}$ back pressure, and rehydrogenation under 100 bar of $\mathrm{H}_{2}$ at $180{ }^{\circ} \mathrm{C}$ for $6 \mathrm{~h}$. After observing the significant formation of $\mathrm{Mg}_{3} \mathrm{~N}_{2}$ from dehydrogenation at $260{ }^{\circ} \mathrm{C}$ [30], the temperature was reduced to $200{ }^{\circ} \mathrm{C}$ to prevent ammonia loss. Previous investigations have shown that decreasing the temperature for hydrogenation/dehydrogenation effectively restrains the particle sizes of the samples, enhancing kinetics during cycling [29]. The isothermal hydrogen discharge data for both the Fritsch and Spex milled samples after the first and fourth discharge cycles are given in Figure 5. In order to study the rates of charge and discharge, the overall rate of grams of hydrogen per second discharged and charged was calculated during the first $30 \mathrm{~min}$ of the cycle. 
Figure 5. Hydrogen desorption curves at standard desorption conditions during first and fourth isothermal discharge cycles of the unmodified material.

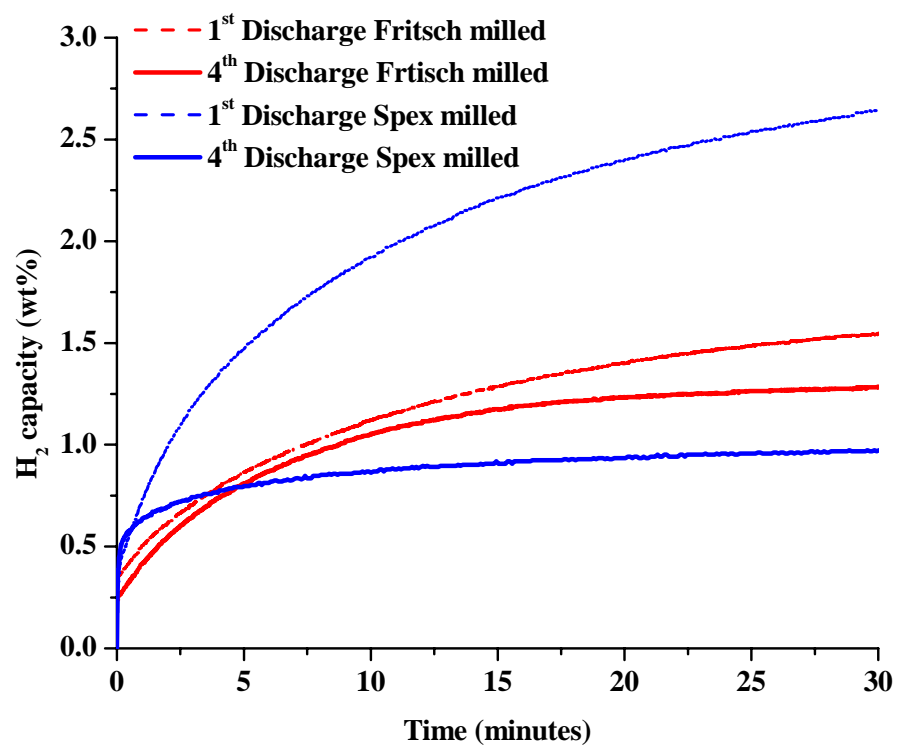

This produced the initial rate in $\left[\mathrm{gH}_{2} / \mathrm{s}\right] / \mathrm{kg}_{\text {material. }}$. This rate was then converted to bed discharge/charge rate using the estimated bed size, in $\mathrm{kg}$, to determine the average absorption hydrogen capacity after 4 cycles. The 2010 DOE technical targets for onboard hydrogen storage for $5 \mathrm{~kg}$ of usable hydrogen are $3 \mathrm{gH}_{2} / \mathrm{s}$ for desorption and $20 \mathrm{gH}_{2} / \mathrm{s}$ for absorption [36]. These average rates are given as a function of cycle in Figure 6. The Spex milled sample initially showed significantly faster dehydrogenation rates than the Fritsch milled sample over 2 isothermal cycles at $200{ }^{\circ} \mathrm{C}$. After the second cycle, the samples showed similar discharge kinetics at values significantly less than the technical target. The possible kinetic barriers to dehydrogenation are discussed below.

Figure 6. Overall bed discharge (A) and recharge (B) rate in $\mathrm{gH}_{2} / \mathrm{s}$ for Spex (red) and Fritsch (blue) milled samples.
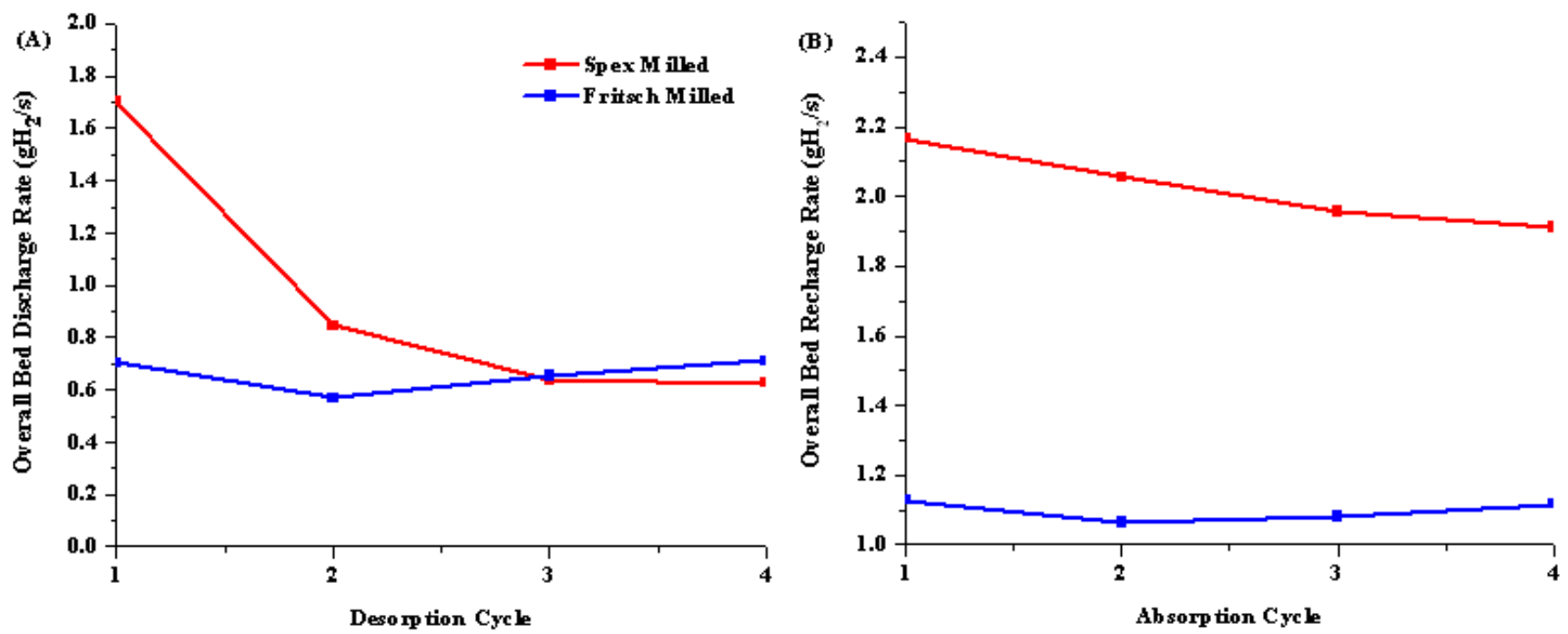

During rehydrogenation, the Spex milled sample was able to maintain a faster recharging rate than the Fritsch milled sample. Between dehydrogenation and rehydrogenation cycles, the sample was 
cooled from $200{ }^{\circ} \mathrm{C}$ to $180{ }^{\circ} \mathrm{C}$ for 20 min while under active vacuum to fully dehydrogenate the sample. Spex milling initially improved the desorption rate close to the DOE technical target but was unable to improve the absorption rate past a tenth of the target.

The average absorption capacity for both materials was $4.4 \mathrm{wt} \%$, which is half of the theoretical hydrogen capacity, indicating that partial dehydrogenation occurred at $200{ }^{\circ} \mathrm{C}$. This correlates well with the TGA and hydrogen emission data seen during the initial decomposition for both samples, which showed one to two hydrogen releases prior to $300{ }^{\circ} \mathrm{C}$ and significant hydrogen release past $300^{\circ} \mathrm{C}$.

Both samples exhibited the same reduction in dehydrogenation capacity seen in our previous work [30]. This reduced capacity was attributed the reduction in diffusion kinetics for the transition metal halide modified mixtures to the formation of lithium salts, irreversible $\mathrm{Mg}_{3} \mathrm{~N}_{2}$ formation, the loss of essential ammonia and the agglomeration of particles during the high temperature dehydrogenation [30]. However, in this experiment, the reduction kinetics can be attributed to the favorable reaction between $\mathrm{LiH}$ and $\mathrm{N}$ to form $\mathrm{Li}_{2} \mathrm{NH}$ [37], essentially hindering the formation of necessary intermediate steps. A thermodynamic study is in progress to determine the changes in reaction enthalpy due to isothermal cycling.

\subsubsection{Phase Identification}

In order to identify the phases existing during the cycling process, an XRD analysis was performed after heating to $200^{\circ} \mathrm{C}$ under pressure during the initial dehydrogenation cycle and after the fourth rehydrogenation cycle at $180{ }^{\circ} \mathrm{C}$. The XRD pattern after heating shows that $\mathrm{LiNH}_{2}$ had begun to decompose owing to the reduction of $\mathrm{LiNH}_{2}$ peaks and formation of $\mathrm{LiH}$ peaks. There was no indication of $\mathrm{MgH}_{2}$ decomposition, as illustrated in Figure 7.

Figure 7. XRD pattern of starting material after heating to $200{ }^{\circ} \mathrm{C}$ under 100 bar of pressure prior to dehydrogenation cycle.

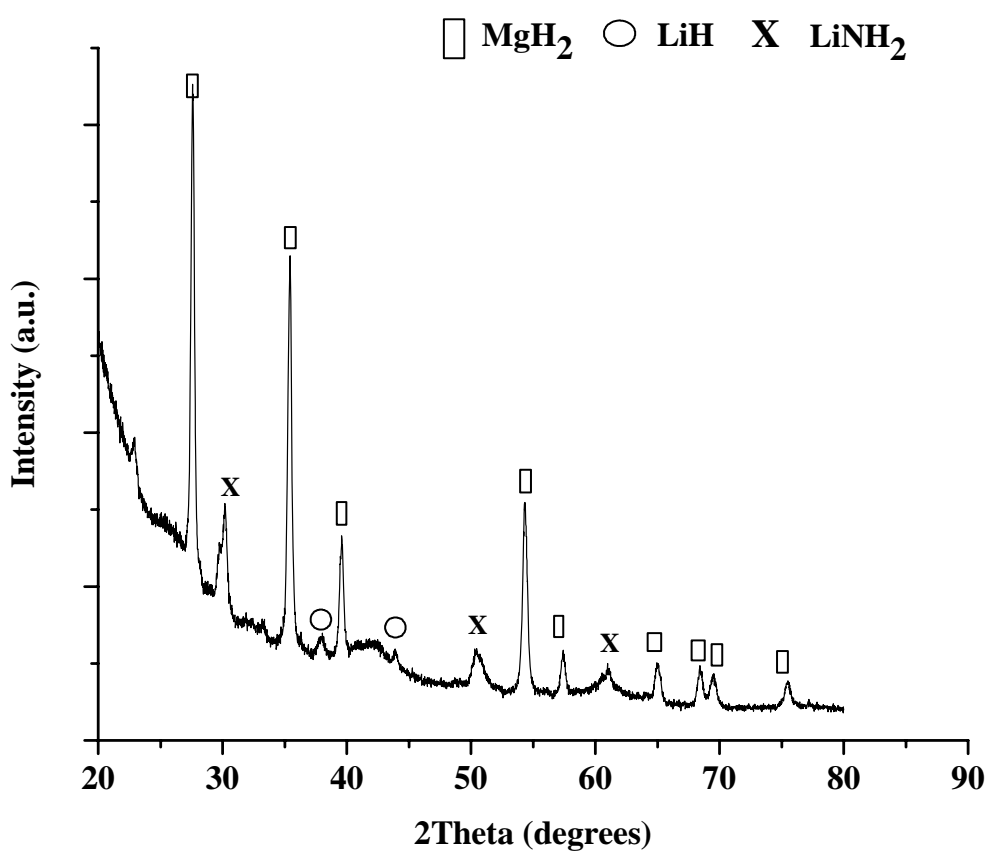


The XRD pattern, seen in Figure 8, of the cycled material shows that $\mathrm{LiH}$ and $\mathrm{MgH}_{2}$ were the predominate products accompanied by $\mathrm{Mg}_{3} \mathrm{~N}_{2}$ formation. The presence of $\mathrm{Mg}_{3} \mathrm{~N}_{2}$ could indicate incomplete rehydrogenation under 100 bar at $180^{\circ} \mathrm{C}$. A future pressure dependence study will be conducted to confirm the sensitivity of the end products to cycling conditions.

Figure 8. XRD pattern of Spex (bottom) and Fritsch (top) milled 1:1 $\mathrm{LiNH}_{2}: \mathrm{MgH}_{2}$ after the 4th hydrogenation.

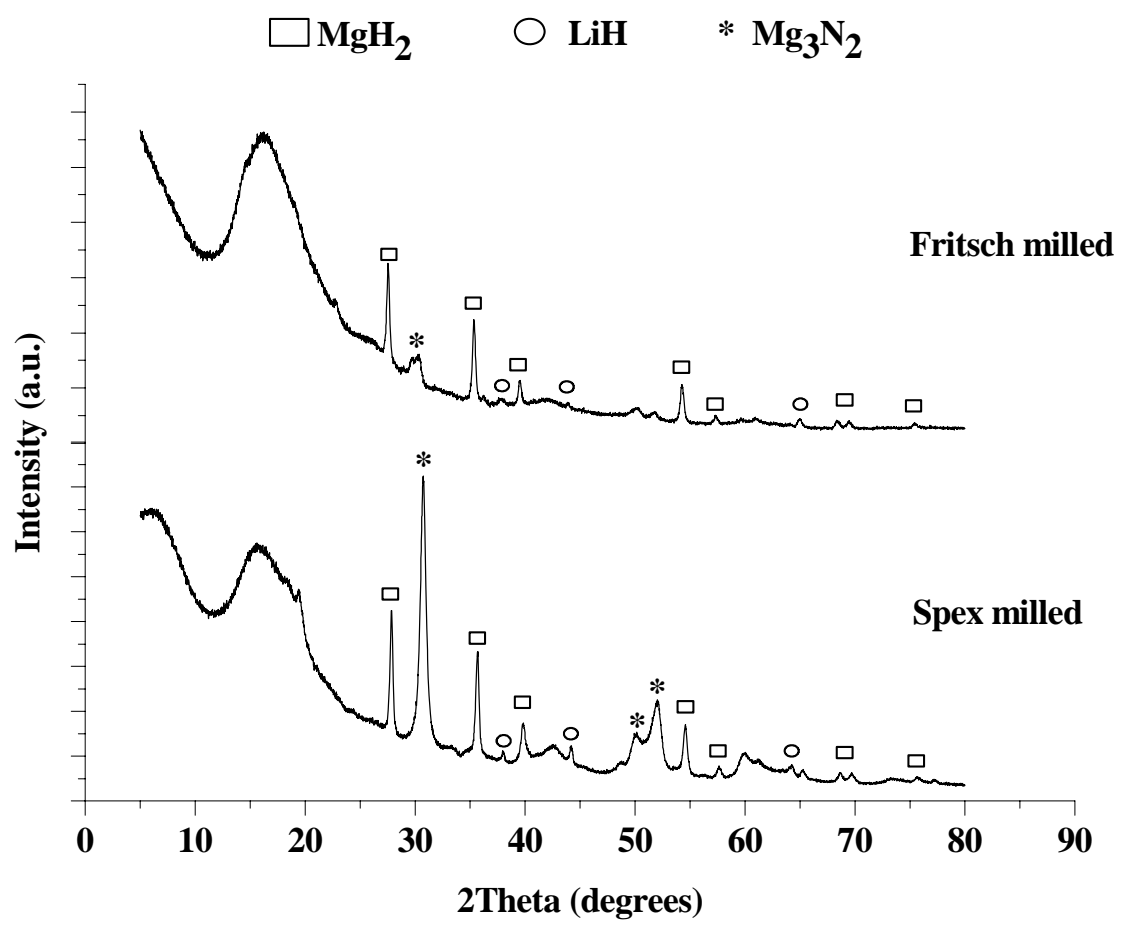

An increase in $\mathrm{MgH}_{2}$ particle size after cycling was observed and calculated for each sample, as reported in Table 1. The particle size increased $20 \mathrm{~nm}$ due to cycling, indicating that particles agglomerated, potentially reducing the overall surface area and subsequently the kinetics of the system.

Table 1. Average particle size of $\mathrm{MgH}_{2}$ before and after cycling.

\begin{tabular}{|l|c|c|}
\hline Milling Conditions & $\begin{array}{l}\text { Average } \mathbf{M g H}_{\mathbf{2}} \text { Particle Size } \\
\text { before Cycling (nm) }\end{array}$ & $\begin{array}{l}\text { Average } \mathbf{M g H}_{\mathbf{2}} \text { Particle Size } \\
\text { after Cycling (nm) }\end{array}$ \\
\hline Spex & 23.6 & 43.5 \\
\hline Fritsch & 35.3 & 49.8 \\
\hline
\end{tabular}

$\mathrm{Mg}\left(\mathrm{NH}_{2}\right)_{2}$, another anticipated product of the reversible sorption reactions, is not identified possibly due to it being in an amorphous state. In the $\mathrm{N}-\mathrm{H}$ stretching region of Raman spectroscopy, bands at $3273 \mathrm{~cm}^{-1}$ and $3326 \mathrm{~cm}^{-1}$ were observed, which are consistent with the formation of $\mathrm{Mg}\left(\mathrm{NH}_{2}\right)_{2}$ as seen in our previous publication [30]. 


\subsection{Modified 1:1 $\mathrm{LiNH}_{2}: \mathrm{MgH}_{2}$ Systems}

\subsubsection{Characterization of As-Milled Modified Material}

The XRD spectra of the as-milled $\mathrm{Fe}_{2} \mathrm{O}_{3}$ and $\mathrm{V}_{2} \mathrm{O}_{5}$, modified samples are given in Figure 9. It was concluded that oxide decomposition during milling did occur owing to the presence of $\mathrm{MgO}$ peaks. Using the Gibbs free energy of reactions between $\mathrm{MgH}_{2}$ and $\mathrm{V}_{2} \mathrm{O}_{5}$ and $\mathrm{Fe}_{2} \mathrm{O}_{3}$, the reduction of the oxides by $\mathrm{MgH}_{2}$ is predicted to be:

$$
\begin{array}{ll}
\mathrm{MgH}_{2}+\mathrm{Fe}_{2} \mathrm{O}_{3} \rightarrow 2 \mathrm{FeO}+\mathrm{MgO}+\mathrm{H}_{2} & \Delta G=-279.6 \mathrm{~kJ} @ 273 \mathrm{~K} \\
3 \mathrm{MgH}_{2}+\mathrm{V}_{2} \mathrm{O}_{5} \rightarrow 2 \mathrm{VO}+3 \mathrm{MgO}+3 \mathrm{H}_{2} & \Delta G=-974.6 \mathrm{~kJ} @ 273 \mathrm{~K}
\end{array}
$$

Therefore, both $\mathrm{V}_{2} \mathrm{O}_{5}$ and $\mathrm{Fe}_{2} \mathrm{O}_{3}$ can be reduced by $\mathrm{MgH}_{2}$ possibly impacting the overall hydrogen capacity and kinetics of the modified systems. Thermodynamic data for the interaction between $\mathrm{LiNH}_{2}$ and the oxides is not available at this time.

Figure 9. $\mathrm{XRD}$ patterns for the as-milled 1:1 $\mathrm{LiNH}_{2}: \mathrm{MgH}_{2}$ mixtures with $1.5 \mathrm{~mol} \% \mathrm{~V}_{2} \mathrm{O}_{5}$ (bottom) or $\mathrm{Fe}_{2} \mathrm{O}_{3}$ modified materials.

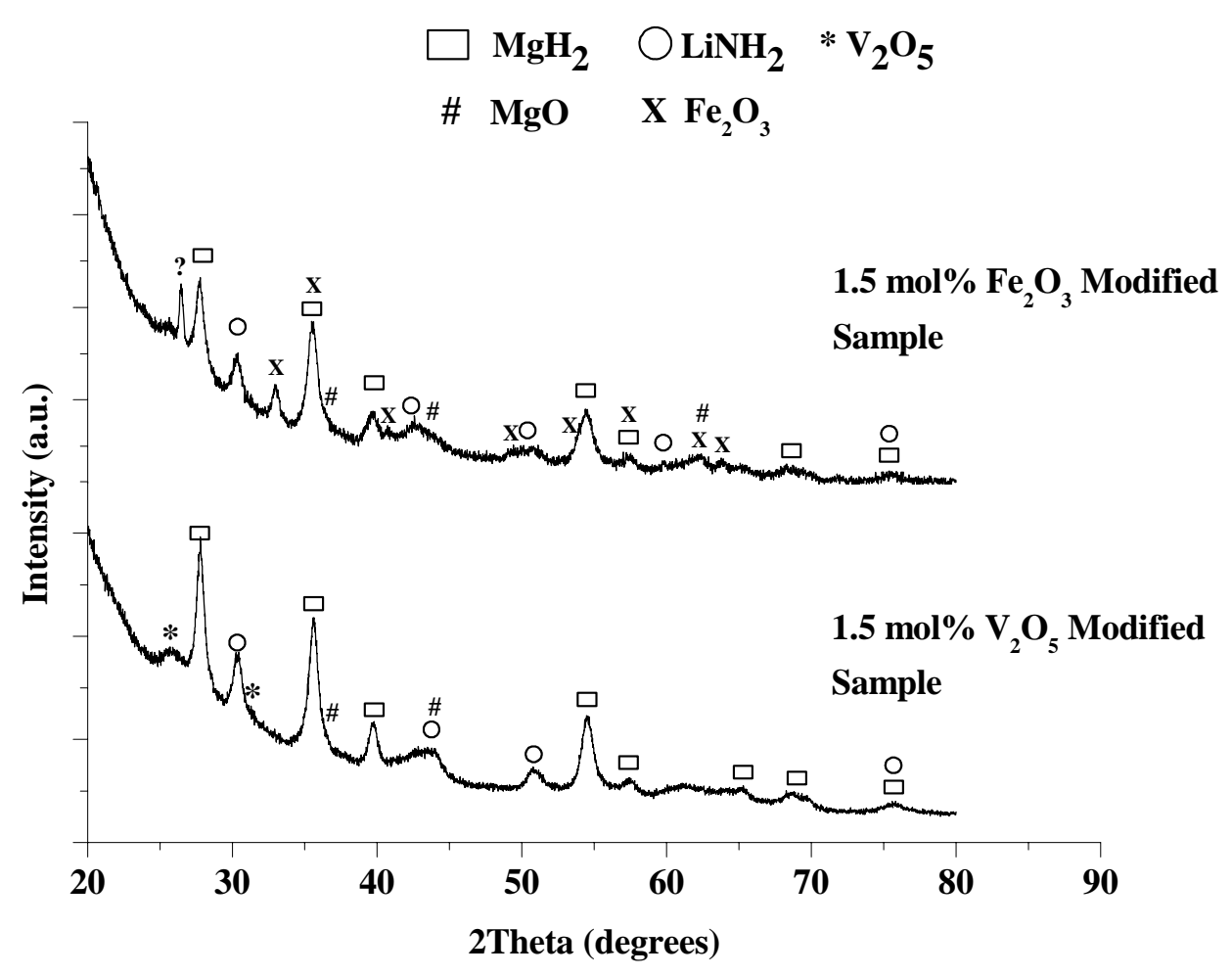

\subsubsection{Decomposition Behavior of As-Milled Modified Material}

Similar to the unmodified composition, two desorption reactions were also observed during the decomposition of the $\mathrm{V}_{2} \mathrm{O}_{5}$ and $\mathrm{Fe}_{2} \mathrm{O}_{3}$ modified 1:1 $\mathrm{LiNH}_{2}: \mathrm{MgH}_{2}$ mixtures. The temperature at which these reactions occurred and the amount of released hydrogen and ammonia for each reaction were dependent on modification composition. Figure 10 shows desorption TGA results ramping from RT to $400{ }^{\circ} \mathrm{C}$ under vacuum at $5{ }^{\circ} \mathrm{C} / \mathrm{min}$. With the addition of oxide modifier, the theoretical hydrogen capacity drops from $8.14 \mathrm{wt} \%$ to $7.45 \mathrm{wt} \%$ and $7.36 \mathrm{wt} \%$ for $\mathrm{Fe}_{2} \mathrm{O}_{3}$ and $\mathrm{V}_{2} \mathrm{O}_{5}$ modified sample, respectively. 
Figure 10. TGA curves for unmodified (black), $1.5 \mathrm{~mol} \% \mathrm{Fe}_{2} \mathrm{O}_{3}$ (red) and $\mathrm{V}_{2} \mathrm{O}_{5}$ (blue) Spex milled 1:1 $\mathrm{LiNH}_{2}: \mathrm{MgH}_{2}$ mixture at $5{ }^{\circ} \mathrm{C} / \mathrm{min}$ from $30^{\circ} \mathrm{C}$ to $400{ }^{\circ} \mathrm{C}$. The initial increase in weight observed during the start of the heating process is attributed to the expansion of the argon carrier gas.

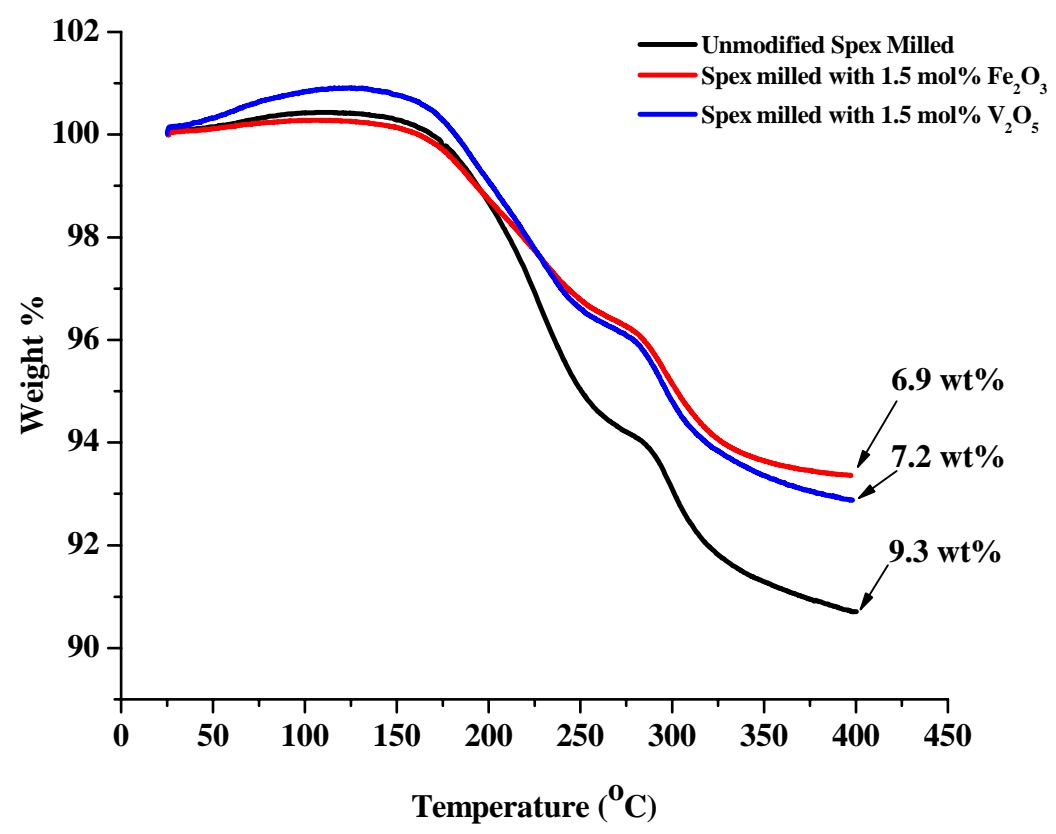

The weight loss of the $\mathrm{Fe}_{2} \mathrm{O}_{3}$ modified sample was $6.9 \mathrm{wt} \%$ and $7.2 \mathrm{wt} \%$ for the $\mathrm{V}_{2} \mathrm{O}_{5}$ modified sample, which are both close to their respective theoretical capacities, indicating that the dehydrogenation process was complete without significant $\mathrm{NH}_{3}$ release. The difference from theoretical weight capacity is attributed to the possible reduction of the oxides by $\mathrm{MgH}_{2}$, potentially releasing hydrogen during the milling process.

From the RGA data for these materials, the initial desorption resulted in two definable hydrogen release events and one ammonia release event. These are summarized in Table 2 with the first and second hydrogen release peaks designated $\mathrm{H}^{1}$ and $\mathrm{H}^{2}$. The two releases can be attributed to the interaction of the two decomposition reactions identified by Akbarzadeh et al. [4]. The addition of both $\mathrm{Fe}_{2} \mathrm{O}_{3}$ and $\mathrm{V}_{2} \mathrm{O}_{5}$ did effectively reduce the temperature of the two hydrogen release by 15 to $20{ }^{\circ} \mathrm{C}$ indicating its improvement on the desorption kinetics of the mixture. From literature, the observed improvement in kinetics is attributed to oxides of metals with multiple valence states, which promote the electronic exchange reactions with hydrogen molecules, accelerating the gas-solid reactions [38]. Typically the transition metal oxide modifier with more valance states proves to be more effective at impacting the sorption kinetics [39].

Table 2. Summary of TGA/RGA decomposition data of the as-milled samples without and with modifiers.

\begin{tabular}{|l|l|l|l|l|l|}
\hline $\begin{array}{l}\text { Compositional } \\
\text { Modification }\end{array}$ & $\begin{array}{l}\text { Theoretical } \\
\mathbf{H}_{2} \text { Weight \% }\end{array}$ & $\begin{array}{l}\text { Total Weight } \\
\text { \% Released }\end{array}$ & $\mathbf{H}^{\mathbf{1}}$ & $\mathbf{H}^{\mathbf{2}}$ & $\begin{array}{l}\text { Peak Ammonia } \\
\text { Release Temperature }\end{array}$ \\
\hline No Modification & 8.2 & 9.3 & 240 & 345 & $285{ }^{\circ} \mathrm{C}$ \\
\hline $1.5 \mathrm{~mol} \% \mathrm{Fe}_{2} \mathrm{O}_{3}$ & 7.45 & 6.9 & 225 & 330 & $270{ }^{\circ} \mathrm{C}$ \\
\hline $1.5 \mathrm{~mol} \% \mathrm{~V}_{2} \mathrm{O}_{5}$ & 7.36 & 7.2 & 220 & 325 & $270{ }^{\circ} \mathrm{C}$ \\
\hline
\end{tabular}


Figure 11. RGA curves for (A) hydrogen and (B) ammonia for as-milled unmodified (black), $\mathrm{Fe}_{2} \mathrm{O}_{3}$ (red) and $\mathrm{V}_{2} \mathrm{O}_{5}$ (blue) modified materials.
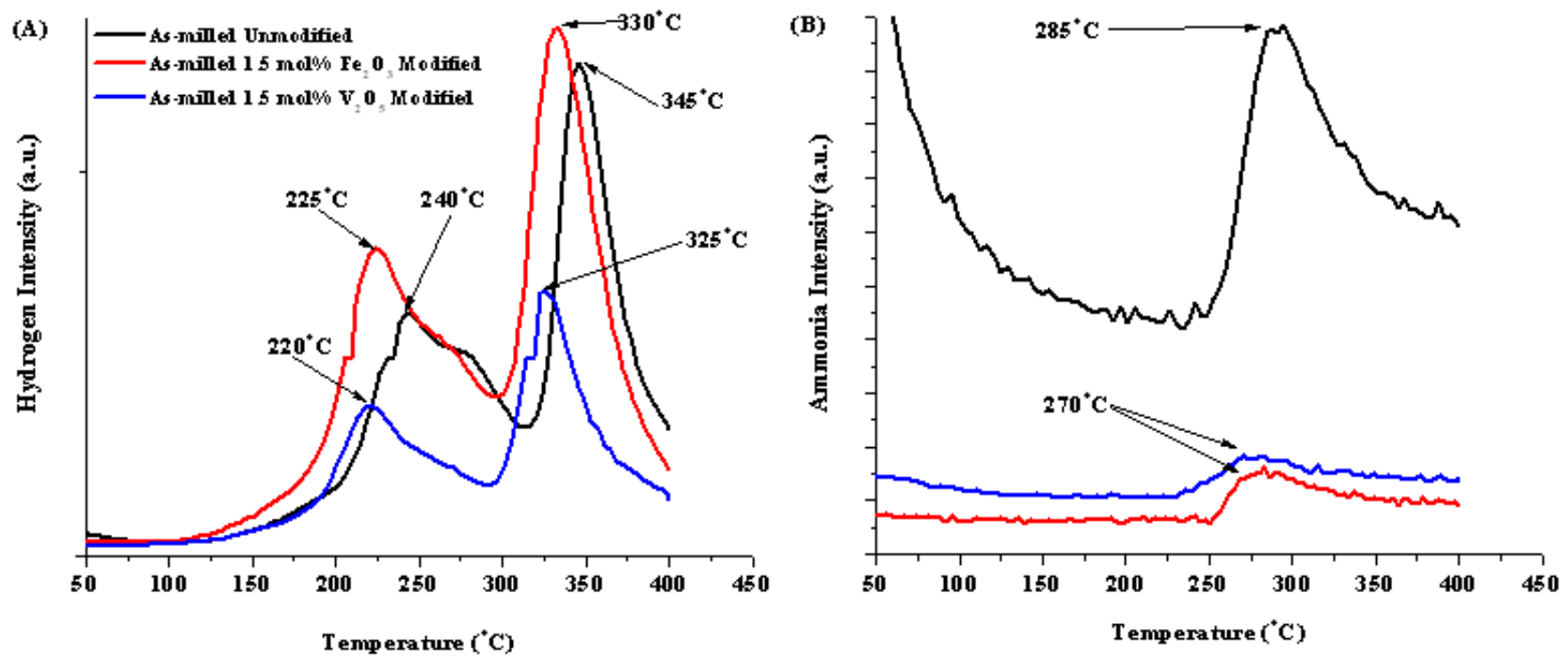

Compositional additions also greatly affected ammonia release. As seen in Table 2 and Figure 11B, both modifiers were effective at reducing the quantity of ammonia release during decomposition compared to the unmodified sample; however, the peak ammonia temperature was lowered by $15^{\circ} \mathrm{C}$. The mechanism behind this is not understood at this time.

\subsubsection{Isothermal Hydrogenation/Dehydrogenation of Modified 1:1 LiNH $: \mathrm{MgH}_{2}$ System}

The impact of the transition metal oxide additions on the average bed discharge/recharging rates of isothermal dehydrogenation and rehydrogenation of 1:1 $\mathrm{LiNH}_{2}: \mathrm{MgH}_{2}$ were investigated under similar conditions to those listed in the previous section. From Figure 12A, the rate of discharge was not dependent on composition as seen by the similar continuous decrease in rate over four cycles for both the oxide modified and unmodified samples.

Figure 12. Bed discharge rate for unmodified (black), $\mathrm{Fe}_{2} \mathrm{O}_{3}$ (red) and $\mathrm{V}_{2} \mathrm{O}_{5}$ (blue) modified samples. The material was discharged under standard conditions.
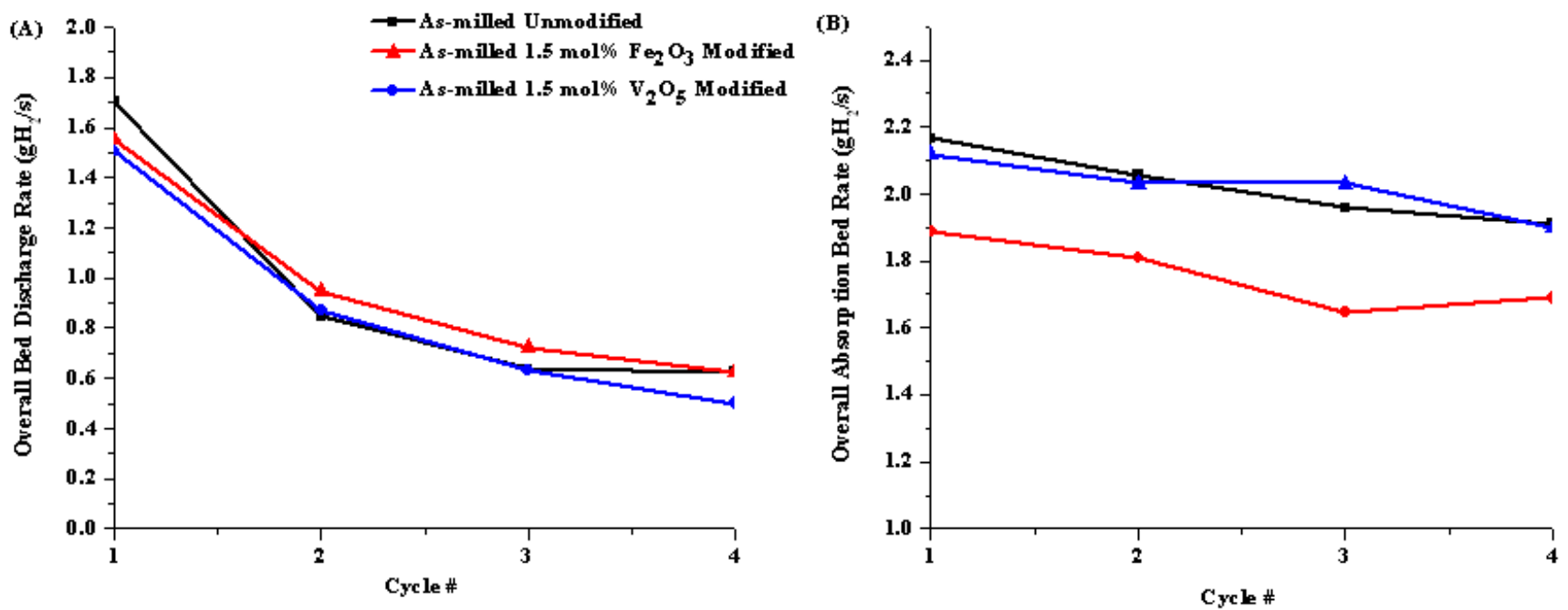
After the second isothermal dehydrogenation cycle, The $\mathrm{Fe}_{2} \mathrm{O}_{3}$ modified material showed slightly faster discharge kinetics than the unmodified and $\mathrm{V}_{2} \mathrm{O}_{5}$ modified samples. These are similar to literature results of discharging $\mathrm{MgH}_{2}$ with different oxide catalysts at $300{ }^{\circ} \mathrm{C}$ into vacuum [38]. The reduction in discharge kinetics over four cycles can potentially be attributed to the exposure to high temperatures which leads to significant coarsening of the microstructure resulting in a slow-down of kinetics [40]. The authors went on to show that oxides have a larger impact on desorption of $\mathrm{MgH}_{2}$ that absorption; therefore, the desorption cycle is more sensitive to catalyst deterioration [40]. Klassan et al. discussed that transition metal oxides showed more improvement on sorption kinetics than their pure metal counterparts [38], indicating that once the oxides are reduced during cycling, they lose their effectiveness [39].

\subsubsection{Phase Identification after Cycling}

Figure 13 gives the results of the XRD analyses performed after the fourth rehydrogenation cycle at $180{ }^{\circ} \mathrm{C}$. The XRD spectra show that $\mathrm{LiH}, \mathrm{Mg}_{3} \mathrm{~N}_{2}$ and $\mathrm{MgH}_{2}$ were the predominant products. Oxide deterioration was observed with the formation of $\mathrm{MgO}$, $\mathrm{VO}$ and $\mathrm{FeO}$ peaks, confirmation of the thermodynamic analysis. However, similar to the unmodified samples, $\operatorname{Mg}\left(\mathrm{NH}_{2}\right)_{2}$ peaks were not identified due possibly to it being in an amorphous state.

Figure 13. XRD pattern of unmodified (bottom), $\mathrm{V}_{2} \mathrm{O}_{5}$ (middle) and $\mathrm{Fe}_{2} \mathrm{O}_{3}$ (top) modified 1:1 $\mathrm{LiNH}_{2}: \mathrm{MgH}_{2}$ after the 4th rehydrogenation cycle.

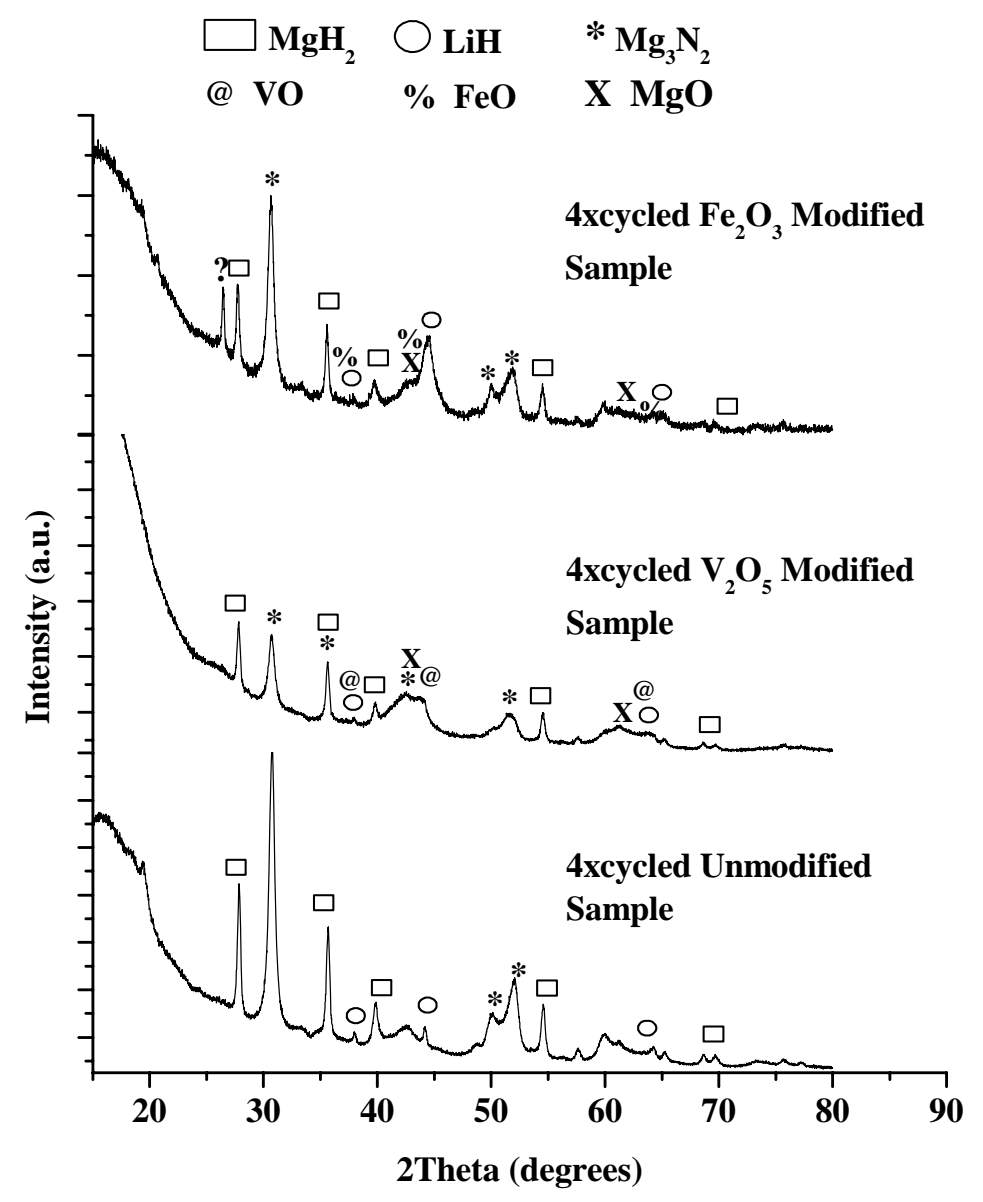




\section{Experimental Section}

The starting materials, lithium amide $\left(\mathrm{LiNH}_{2}, 95 \%\right.$, Aldrich), magnesium hydride $\left(\mathrm{MgH}_{2},>97 \%\right.$, Gelest Inc.), vanadium oxide $\left(\mathrm{V}_{2} \mathrm{O}_{5},>99 \%\right.$, Aldrich) and iron oxide $\left(\mathrm{Fe}_{2} \mathrm{O}_{3},>99 \%\right.$, Aldrich) were purchased and used without alteration. Samples were prepared using a Fritch planetary or Spex milling technique. Three grams of 1:1 $\mathrm{LiNH}_{2}: \mathrm{MgH}_{2}$ without modifiers were loaded into the Fritsch milling jars while in the argon glove box. A 30:1 ball to sample weight ratio for the Fritsch mill and a 10:1 ratio for Spex milling were maintained. The Fritsch milled powders were milled for $2 \mathrm{~h}$ with 30 min cycles at $500 \mathrm{rpm}$ while the Spex mill was also milled for $2 \mathrm{~h}$ in 30 min cycles.

Powder X-ray Diffraction (XRD) patterns of the as-milled, dehydrogenated and rehydrogenated materials were collected on a Rigaku Dmax/2100 $\left(\mathrm{Cu} \mathrm{K} \mathrm{K}_{\alpha}\right.$ radiation). The samples were mounted on a glass slide and covered with Kapton ${ }^{\circledR}$ film while under argon. The XRD patterns were recorded from $2 \theta$ spanning 5 to $80^{\circ}$ with a scanning rate of $0.02^{\circ} / \mathrm{min}$.

Effluent gas composition was monitored as a function of temperature and time using a thermogravimetric analyzer (TGA) coupled with a residual gas analyzer (RGA). The TGA was located inside an argon glove box to prevent the samples from oxidizing. Five gram samples were loaded into a stainless steel microbalance pan and heated from $30{ }^{\circ} \mathrm{C}$ to $400{ }^{\circ} \mathrm{C}$ with a heating rate of $5{ }^{\circ} \mathrm{C} / \mathrm{min}$ under a constant flow of argon gas. The effluent gases from the TGA were constantly monitored for $\mathrm{H}_{2}$ (mass 2), $\mathrm{NH}_{3}$ (mass 16 and 17), $\mathrm{H}_{2} \mathrm{O}$ (mass 18) and $\mathrm{O}_{2}$ (mass 32) gases using a Hiden Analytical residual gas analyzer (RGA).

Hydrogen desorption and absorption kinetics measurements were carried out using a Sievert's apparatus (PCTPro-2000, Setaram). Approximate $0.5 \mathrm{~g}$ samples were loaded into a stainless steel reactor vial and sealed in a glovebox. Standard isothermal discharge procedure called for heating of the sample under 110 bar or greater, based on the estimated equilibrium pressure using the enthalpy determined by Alapati et al. [22] and the entropy listed for the 2:1 $\mathrm{LiNH}_{2}: \mathrm{MgH}_{2}$ mixture at $210{ }^{\circ} \mathrm{C}$ by Markmaitree et al [34], in order to prevent side reactions to occur while heating. During heating from RT to $200^{\circ} \mathrm{C}$, the change in pressure of the sample reactor was noted in order to account for prematurely discharged $\mathrm{H}_{2}$. Once $200^{\circ} \mathrm{C}$ was reached, the sample was discharged into the largest reservoir $(1170 \mathrm{~mL})$ with a backpressure of 1 bar. During subsequent recharging cycles, the sample was cooled from $200{ }^{\circ} \mathrm{C}$ to $180^{\circ} \mathrm{C}$ for 20 min under active vacuum and then exposed to 100 bar of $\mathrm{H}_{2}$ pressure. During the dehydrogenation and hydrogenation cycles, sample temperature and reservoir pressures were recorded.

\section{Conclusions}

In this paper, we have compared the effects of ball milling techniques and compositional modifications on the dehydrogenation/rehydrogenation rates, the temperature of initial hydrogen release and the amount of ammonia released from unmodified and modified 1:1 $\mathrm{MgH}_{2}$ and $\mathrm{LiNH}_{2}$. Spex milling the mixture resulted in reduced ammonia release and relatively faster sorption kinetics resulting from particle size reduction and increase in defect density. The addition of $\mathrm{Fe}_{2} \mathrm{O}_{3}$ and $\mathrm{V}_{2} \mathrm{O}_{5}$ modifiers significantly reduced the amount of ammonia emission during the initial decomposition. After four isothermal sorption cycles, the $\mathrm{V}_{2} \mathrm{O}_{5}$ modified mixture showed faster sorption kinetics than 
the $\mathrm{Fe}_{2} \mathrm{O}_{3}$ mixture, indicating possible higher stability and promotion of hydrogen absorption through a higher defect density. Further studies are needed to fully understand the cycling pathways and the role the transition metal oxides had in sorption kinetics.

\section{Acknowledgements}

The authors thank H. zur Loye, Daniel Bugaris and Muktha Bharathy at the University of South Carolina and Susan Michele Everett from the University of Tennessee for their efforts on performing XRD analyses; Z. Fang at the University of Utah, Ragaiy Zidan of Savannah River National Laboratory and Ned Stetson of the U.S. DOE for helpful discussions; and Joseph Wheeler at Savannah River National Laboratory for maintaining the laboratory. This work is financially supported by the US-DOE through the Metal Hydride Center of Excellence.

\section{References}

1. Pinkerton, F.E. Decomposition kinetics of lithium amide for hydrogen storage materials. J. Alloys Compd. 2005, 400, 76-82.

2. Matsumoto, M.; Haga, T.; Kawai, Y.; Kojima, Y. Hydrogen desorption reactions of Li-N-H hydrogen storage system: Estimation of activation free energy. J. Alloys Compd. 2007, 439, 358-362.

3. Chen, P.; Xiong, Z.; Luo, J.; Lin, J.; Tan, K.L. Interaction of hydrogen with metal nitrides and imides. Nature 2002, 420, 302-304.

4. Akbarzadeh, A.R.; Ozolinšs, V.; Wolverton, C. First-Principles Determination of Multicomponent Hydride Phase Diagrams: Application to the Li-Mg-N-H System. Adv. Mater. 2007, 19, 3233-3239.

5. Luo, W.; Sickafoose, S. Thermodynamic and structural characterization of the $\mathrm{Mg}-\mathrm{Li}-\mathrm{N}-\mathrm{H}$ hydrogen storage system. J. Alloys Compd. 2006, 407, 274-281.

6. Araujo, C.M.; Scheicher, R.H.; Ahuja, R. Thermodynamic analysis of hydrogen sorption reactions in Li-Mg-N-H systems. Appl. Phys. Lett. 2008, 92, 021907-021903.

7. Luo, W. $\mathrm{LiNH}_{2}-\mathrm{MgH}_{2}$ : A viable hydrogen storage system. J. Alloys Compd. 2004, 381, 284-287.

8. Leng, H.Y.; Ichikawa, T.; Hino, S.; Hanada, N.; Isobe, S.; Fujii, H. New Metal-N-H System Composed of $\mathrm{Mg}\left(\mathrm{NH}_{2}\right)_{2}$ and $\mathrm{LiH}$ for Hydrogen Storage. J. Phys. Chem. B 2004, 108, 8763-8765.

9. Luo, W.; Rönnebro, E. Towards a viable hydrogen storage system for transportation application. J. Alloys Compd. 2005, 404-406, 392-395.

10. Xiong, Z.; Wu, G.; Hu, J.; Chen, P. Ternary Imides for Hydrogen Storage. Adv. Mater. 2004, 16, $1522-1525$.

11. Hu, J.; Fichtner, M. Formation and Stability of Ternary Imides in the Li-Mg-N-H Hydrogen Storage System. Chem. Mater. 2009, 21, 3485-3490.

12. Janot, R.; Eymery, J.-B.; Tarascon, J.-M. Investigation of the processes for reversible hydrogen storage in the Li-Mg-N-H system. J. Power Sources 2007, 164, 496-502.

13. Weidner, E.; Dolci, F.; Hu, J.; Lohstroh, W.; Hansen, T.; Bull, D.J.; Fichtner, M. Hydrogenation Reaction Pathway in $\mathrm{Li}_{2} \mathrm{Mg}(\mathrm{NH})_{2}$. J. Phys. Chem. C 2009, 113, 15772-15777. 
14. Dolci, F.; Weidner, E.; Hoelzel, M.; Hansen, T.; Moretto, P.; Pistidda, C.; Brunelli, M.; Fichtner, M.; Lohstroh, W. In-situ neutron diffraction study of magnesium amide/lithium hydride stoichiometric mixtures with lithium hydride excess. Int. J. Hydrog. Energy 2010, 35, 5448-5453.

15. Yang, J.; Sudik, A.; Wolverton, C. Activation of hydrogen storage materials in the $\mathrm{Li}-\mathrm{Mg}-\mathrm{N}-\mathrm{H}$ system: Effect on storage properties. J. Alloys Compd. 2007, 430, 334-338.

16. Chen, P.; Xiong, Z.; Yang, L.; Wu, G.; Luo, W. Mechanistic Investigations on the Heterogeneous Solid-State Reaction of Magnesium Amides and Lithium Hydrides. J. Phys. Chem. B 2006, 110, 14221-14225.

17. Leng, H.; Ichikawa, T.; Hino, S.; Nakagawa, T.; Fujii, H. Mechanism of Hydrogenation Reaction in the Li-Mg-N-H System. J. Phys. Chem. B 2005, 109, 10744-10748.

18. Aoki, M.; Noritake, T.; Nakamori, Y.; Towata, S.; Orimo, S. Dehydriding and rehydriding properties of $\mathrm{Mg}\left(\mathrm{NH}_{2}\right)_{2}$-LiH systems. J. Alloys Compd. 2007, 446-447, 328-331.

19. Aoki, M.; Noritake, T.; Kitahara, G.; Nakamori, Y.; Towata, S.; Orimo, S. Dehydriding reaction of $\mathrm{Mg}\left(\mathrm{NH}_{2}\right)_{2}-\mathrm{LiH}$ system under hydrogen pressure. J. Alloys Compd. 2007, 428, 307-311.

20. Chu, L.; Yongfeng, L.; Kun, L.; Bo, L.; Mingxia, G.; Hongge, P.; Qidong, W. Reaction Pathways Determined by Mechanical Milling Process for Dehydrogenation/Hydrogenation of the $\mathrm{LiNH}_{2}-\mathrm{MgH}_{2}$. Chem. A Eur. J. 2010, 16, 693-702.

21. Nakamori, Y.; Kitahara, G.; Miwa, K.; Ohba, N.; Noritake, T.; Towata, S.; Orimo, S. Hydrogen storage properties of Li-Mg-N-H systems. J. Alloys Compd. 2005, 404-406, 396-398.

22. Alapati, S.V.; Johnson, J.K.; Sholl, D.S. Identification of Destabilized Metal Hydrides for Hydrogen Storage Using First Principles Calculations. J. Phys. Chem. B 2006, 110, 8769-8776.

23. Lu, J.; Fang, Z.Z.; Choi, Y.J.; Sohn, H.Y. Potential of Binary Lithium Magnesium Nitride for Hydrogen Storage Applications. J. Phys. Chem. C 2007, 111, 12129-12134.

24. Lu, J.; Choi, Y.J.; Fang, Z.Z.; Sohn, H.Y. Effect of milling intensity on the formation of LiMgN from the dehydrogenation of $\mathrm{LiNH}_{2}-\mathrm{MgH}_{2}$ (1:1) mixture. J. Power Sources 2010, 195, 1992-1997.

25. Liu, Y.; Zhong, K.; Gao, M.; Wang, J.; Pan, H.; Wang, Q. Hydrogen Storage in a $\mathrm{LiNH}_{2}-\mathrm{MgH}_{2}$ (1:1) System. Chem. Mater. 2008, 20, 3521-3527.

26. Liang, C.; Liu, Y.; Luo, K.; Li, B.; Gao, M.; Pan, H.; Wang, Q. Reaction Pathways Determined by Mechanical Milling Process for Dehydrogenation/Hydrogenation of the $\mathrm{LiNH}_{2} / \mathrm{MgH}_{2}$ System. Chem. A Eur. J. 2010, 16, 693-702.

27. Osborn, W.; Markmaitree, T.; Shaw, L.L. Evaluation of the hydrogen storage behavior of a $\mathrm{LiNH}_{2}+\mathrm{MgH}_{2}$ system with 1:1 ratio. J. Power Sources 2007, 172, 376-378.

28. Michel, K.J.; Akbarzadeh, A.R.; Ozolins, V. First-Principles Study of the Li-Mg-N-H System: Compound Structures and Hydrogen-Storage Properties. J. Phys. Chem. C 2009, 113, 14551-14558.

29. Liu, Y.; Zhong, K.; Luo, K.; Gao, M.; Pan, H.; Wang, Q. Size-Dependent Kinetic Enhancement in Hydrogen Absorption and Desorption of the Li-Mg-N-H System. J. Am. Chem. Soc. 2009, 131, 1862-1870.

30. Price, C.; Gray, J.; Lascola, R.; Anton, D. The Affects of Halide Modifiers on the Sorption Kinetics of 1:1 $\mathrm{LiNH}_{2}: \mathrm{MgH}_{2}$. Int. J. Hydrog. Energy 2010, in press.

31. Bald, C.P.; Hereijgers, B.P.C.; Bitter, J.H.; de Jong, K.P. Sodium Alanate Nanoparticles-Linking Size to Hydrogen Storage Properties. J. Am. Chem. Soc. 2008, 130, 6761-6765. 
32. Varin, R.A.; Jang, M.; Polanski, M. The effects of ball milling and molar ratio of LiH on the hydrogen storage properties of nanocrystalline lithium amide and lithium hydride $(\mathrm{LiNH} 2+\mathrm{LiH})$ system. J. Alloys Compd. 2010, 491, 658-667.

33. Markmaitree, T.; Osborn, W.; Shaw, L.L. Comparative studies of reaction rates of $\mathrm{NH}_{3}$ with $\mathrm{MgH}_{2}$ and LiH. J. Power Sources 2008, 180, 535-538.

34. Markmaitree, T.; Osborn, W.; Shaw, L.L. Comparisons between $\mathrm{MgH}_{2^{-}}$and $\mathrm{LiH}$-containing systems for hydrogen storage applications. Int. J. Hydrog. Energy 2008, 33, 3915-3924.

35. Luo, W.; Stewart, K. Characterization of $\mathrm{NH}_{3}$ formation in desorption of $\mathrm{Li}-\mathrm{Mg}-\mathrm{N}-\mathrm{H}$ storage system. J. Alloys Compd. 2007, 440, 357-361.

36. DOE Targets for Onboard Hydrogen Storage Systems for Light-Duty Vehicles. Available online: http://www1.eere.energy.gov/hydrogenandfuelcells/storage/pdfs/targets_onboard_hydro_storage.pdf (accessed on 1 December 2010).

37. Hu, Y.H.; Ruckenstein, E. Ultrafast Reaction between $\mathrm{LiH}$ and $\mathrm{NH}_{3}$ during $\mathrm{H}_{2}$ Storage in $\mathrm{Li}_{3} \mathrm{~N}$. J. Phys. Chem. A 2003, 107, 9737-9739.

38. Barkhordarian, G.; Klassen, T.; Bormann, R. Fast hydrogen sorption kinetics of nanocrystalline $\mathrm{Mg}$ using $\mathrm{Nb}_{2} \mathrm{O}_{5}$ as catalyst. Scripta Mater. 2003, 49, 213-217.

39. Huang, Z.G.; Guo, Z.P.; Calka, A.; Wexler, D.; Lukey, C.; Liu, H.K. Effects of iron oxide $\left(\mathrm{Fe}_{2} \mathrm{O}_{3}\right.$, $\mathrm{Fe}_{3} \mathrm{O}_{4}$ ) on hydrogen storage properties of Mg-based composites. J. Alloys Compd. 2006, 422, 299-304.

40. Dehouche, Z.; Klassen, T.; Oelerich, W.; Goyette, J.; Bose, T.K.; Schulz, R. Cycling and thermal stability of nanostructured $\mathrm{MgH}_{2}-\mathrm{Cr}_{2} \mathrm{O}_{3}$ composite for hydrogen storage. J. Alloys Compd. 2002, 347, 319-323.

(C) 2011 by the authors; licensee MDPI, Basel, Switzerland. This article is an open access article distributed under the terms and conditions of the Creative Commons Attribution license (http://creativecommons.org/licenses/by/3.0/). 